\title{
PERBEDAAN KEMAMPUAN BERPIKIR KREATIF MELALUI PEMBELAJARAN MATEMATIKA BERBANTUAN PUZZLE DAN GEOGEBRA
}

\section{(DIFFERENCES OF INCREASE CREATIVITY ABILITY THROUGH PUZZLE AND GEOGEBRA ASSISTED MATHEMATICAL LEARNING)}

\section{Dinna Cilvia Asri', Bobbi Rahman', Surya Wijaya ${ }^{3}$}

${ }^{1}$ MTs Negeri 1 Banyuasin, dinnacasri@gmail.com

2STKIP Surya, bobbirahman1@gmail.com

3Yayasan Simetri, suryaming@gmail.com

\section{Info Artikel \\ Received May 22, 2020 \\ Revised Jul 21, 2020 \\ Accepted Aug 29, 2020 \\ Kata Kunci: \\ Berpikir Kreatif, Gender, GeoGebra, Matematika, Puzzle}

\section{Cara merujuk artikel ini:}

Asri, D.C., Rahman, B., \& Wijaya, S. (2020).

Perbedaan Kemampuan Berpikir Kreatif melalui Pembelajaran Matematika Berbantuan Puzzle dan Geogebra. Vygotsky: Jurnal Pendidikan Matematika dan Matematika, 2 (2), pp. 7889. Diunduh dari http://jurnalpendidikan. unisla.ac.id/index.php/ $\mathrm{VoJ} /$ article/view/223/pdf

\begin{abstract}
Creativity ability of junior high school students have not been optimized. One effort to increase it is by use instructional media, such as puzzle and GeoGebra. Purpose of this research was to investigate differences creativity ability between students who learning by puzzle and GeoGebra reviewed by gender. Research type was quasiexperiment with nonequivalent control group design. Sample were two groups from grade VIII in Junior High School 1 Tangerang. Data collected by pretest and posttest. Based on ANOVA Two Tail Test, there are differences increase creativity ability students who learning by puzzle and GeoGebra. If reviewed by gender, there is no difference increase. Besides that, the factors of instructional media and gender do not equally affect the increase creativity ability.

\begin{tabular}{l}
\hline Abstrak \\
Kemampuan berpikir kreatif siswa SMP belum \\
optimal. Salah satu upayanya ialah dengan \\
penggunaan media seperti puzzle dan GeoGebra. \\
Penelitian ini bertujuan untuk mengetahui perbedaan \\
peningkatan kemampuan berpikir kreatif siswa yang \\
belajar menggunakan puzzle dan GeoGebra serta \\
ditinjau berdasarkan gender. Jenis penelitian ini adalah \\
kuasi eksperimen dengan Nonequivalent Control Group \\
Design. Sampel yang digunakan yaitu dua kelas VIII \\
SMPN 1 Kota Tangerang. Pengumpulan data dengan \\
soal pretest dan postest berbentuk uraian. Berdasarkan \\
uji ANOVA dua jalur disimpulkan bahwa terdapat \\
perbedaan kemampuan berpikir kreatif siswa kelas \\
puzzle dan GeoGebra. Apabila ditinjau berdasarkan \\
gender, kemampuan berpikir kreatif siswa tidak \\
terdapat perbedaan. Selain itu, faktor media dan \\
gender tidak sama-sama memengaruhi peningkatan \\
kemampuan berpikir kreatif siswa.
\end{tabular}
\end{abstract}

Copyright $\odot 2020$ Vygotsky: Jurnal Pendidikan Matematika dan Matematika. All right reserved 


\section{PENDAHULUAN}

Pengembangan kreativitas siswa perlu dilakukan untuk dapat memberikan sumbangan terhadap perkembangan ilmu pengetahuan (Noer, 2014). Rahman (2012) mengungkapkan bahwa kemampuan berpikir kreatif dalam proses pembelajaran matematika masih kurang mendapat perhatian. Selain itu, proses pembelajaran di sekolah pada umumnya kurang mengembangkan kemampuan berpikir kreatif siswa karena guru masih terbiasa memberikan soal rutin yang memiliki satu penyelesaian (Sari \& Yuniarti, 2015).

Berpikir kreatif pada pembelajaran matematika menurut Haylock (1987) merupakan kemampuan untuk dapat menyelesaikan permasalahan matematika dengan berbagai cara yang tidak biasa dilakukan. Menurut Ervynck (1991), berpikir kreatif pada pembelajaran matematika diartikan sebagai kemampuan untuk menghasilkan konsep dan menggabungkan ide-ide yang berkaitan dengan matematika. Berdasarkan pendapat yang telah dijelaskan dapat disimpulkan bahwa kemampuan berpikir kreatif pada pembelajaran matematika merupakan kombinasi dari kemampuan menyelesaikan masalah dengan menggunakan berbagai ide, menghasilkan konsep, dan menggabungkan ide-ide yang berkaitan dengan matematika. Indikator yang peneliti gunakan berdasarkan hasil yang dikemukakan oleh Torrance (1972) dan Hendriana \& Sumarmo (2014). Adapun indikator yang digunakan pada penelitian untuk mengukur kemampuan berpikir kreatif adalah:

1. Kelancaran, yaitu kemampuan untuk dapat memikirkan dan mencetuskan banyak ide atau kemungkinan dari suatu permasalahan.

2. Kelenturan, yaitu kemampuan untuk memberikan ide-ide atau gagasan jawaban yang berbeda dengan sudut pandang yang berbeda-beda.

3. Keaslian, yaitu kemampuan untuk dapat menggunakan ide-ide yang tidak biasa digunakan atau dengan cara yang tidak lazim.

4. Elaborasi, yaitu kemampuan untuk dapat mengembangkan atau merincikan ide atau gagasan.

Fakta menunjukkan bahwa kemampuan berpikir kreatif siswa pada pembelajaran matematika di Indonesia belum optimal. Berdasarkan hasil wawancara yang dilakukan dengan salah satu guru mata pelajaran matematika di SMP Negeri 1 Kota Tangerang, kemampuan berpikir kreatif siswa rendah karena siswa hanya dapat menyelesaikan permasalahan menggunakan cara yang diberikan ketika terjadi proses pembelajaran. Selain itu, kemampuan berpikir kreatif siswa Indonesia yang masih rendah juga dapat dilihat dari studi Internasional, yaitu Trends in International Mathematics and Science Study (TIMSS) pada 2011 dan Program for International Students Assesment (PISA) pada 2015. Menurut Wardhani dan Rumiati (2011), salah satu karakteristik dari soalsoal TIMSS dan PISA yaitu adanya kreativitas dalam penyelesaiannya. Hal ini menunjukkan bahwa soal tersebut mengukur kemampuan berpikir kreatif. 
Adapun upaya yang dapat dilakukan untuk meningkatkan kemampuan berpikir kreatif siswa salah satunya adalah penggunaan media khusunya pada proses pembelajaran matematika dapat membantu meningkatkan kemampuan berpikir kreatif siswa. Hal ini sesuai dengan pendapat Amri (2015) yang mengungkapkan bahwa penggunaan media dalam proses pembelajaran merupakan salah satu kegiatan yang dapat dilakukan untuk menciptakan proses pembelajaran yang aktif dan kreatif. Namun, pemanfaatan media dalam proses pembelajaran matematika belum banyak digunakan oleh guru (Primasari, Zulfiati, \& Herlanti, 2014). Padahal, media pembelajaran dapat digunakan untuk membantu siswa melakukan eksplorasi ketika pembelajaran berlangsung sehingga dapat mengasah kemampuan berpikir kreatif (Hartadiyati, Utami, \& Rubowo, 2015). Hal ini sejalan dengan yang disampaikan guru matematika SMP Negeri 1 Kota Tangerang bahwa pemanfaatan media pada proses pembelajaran masih jarang dilakukan.

Terdapat beberapa jenis media pembelajaran yang dapat digunakan pada proses pembelajaran, misalnya puzzle dan GeoGebra. Menurut Seels dan Glasgow (Arsyad, 2015) media puzzle merupakan salah satu contoh media tradisional, sedangkan software GeoGebra merupakan salah satu contoh media mutakhir. Media puzzle adalah permainan yang menyatukan suatu kepingan-kepingan untuk dipasangkan dan membentuk suatu bentuk yang diinginkan (Dewi, Kusuma, \& Kurniasih, 2016). GeoGebra adalah sebuah perangkat lunak yang dapat membantu menyelesaikan permasalahan geometri dan aljabar (Hohenwarter \& Fuchs, 2004).

Adanya penggunaan media puzzle pada proses pembelajaran dapat menuntut siswa untuk menemukan berbagai macam bentuk penyelesaian yang merupakan salah satu indikator dari kemampuan berpikir kreatif. Berdasarkan hasil penelitian yang dilakukan oleh Anthaqo \& Muhsetyo (2013) menunjukkan hasil bahwa pembelajaran yang menggunakan puzzle dapat meningkatkan hasil belajar siswa karena diperlukan ide untuk dapat menyelesaikan puzzle yang diberikan selama proses pembelajaran. Menurut Aroya \& Yusuf (2013) penggunaan media puzzle dapat membantu siswa untuk berpikir kreatif dan bergerak aktif. Selain itu, menurut Hartadiyati, Utami, \& Rubowo (2015). Bermain puzzle menuntut siswa berpikir secara kreatif menyusun setiap potongan menjadi bentuk yang utuh. Adapun perbedaan puzzle yang digunakan dalam penelitian ini dibandingkan penelitian yang telah ada adalah pada penelitian ini puzzle dibuat sendiri khusus untuk pembelajaran pada materi teorema Pythagoras.

Saat melakukan eksplorasi menggunakan GeoGebra juga dapat membantu siswa untuk menemukan berbagai macam ukuran yang berbeda. Menurut Mahmudi (2010) eksplorasi menggunakan GeoGebra dapat memunculkan ide-ide baru. Selain itu, berdasarkan hasil penelitian yang dilakukan oleh Wardaya, Kurniasih, \& Maryam (2014) di SMP Muhammadiyah Purworejo menunjukkan bahwa kreativitas belajar siswa 
meningkat setelah mengikuti pembelajaran berbantuan GeoGebra dikarenakan siswa lebih merasa tertantang dalam bereksplorasi menggunakan GeoGebra. Selanjutnya, penggunaan GeoGebra memungkinkan banyak eksplorasi yang dilakukan sehingga dapat merangsang kemampuan berpikir kreatif siswa (Atikasari \& Kurniasih, 2015).

Selain penggunaan media pembelajaran, kemampuan berpikir kreatif siswa juga dipengaruhi oleh perbedaan gender. Berdasarkan hasil penelitian yang dilakukan oleh Herman (2007) menunjukkan bahwa siswa laki-laki memiliki tingkat pencapaian yang lebih baik daripada siswa perempuan untuk kemampuan matematis tingkat tinggi. Menurut Nurmasari, Kusmayadi, \& Riyadi (2014), kemampuan berpikir kreatif siswa perempuan tidak sama dengan siswa laki-laki. Pendapat lain dijelaskan oleh Galam-bos, Berenbaum dan McHale (Santrock, 2014) bahwa kemampuan intelektual tidak terdapat perbedaan secara keseluruhan antara siswa laki-laki dan perempuan melainkan perbedaan gender muncul pada kemampuan matematis dan verbal. Hal serupa juga dikemukakan oleh Katminingsih \& Widodo (2015) bahwa kemampuan berpikir kreatif siswa laki-laki lebih baik dari pada siswa perempuan.

Berdasarkan uraian yang telah disebutkan maka peneliti melakukan penelitian menggunakan dua media berupa media puzzle dan media GeoGebra yang digunakan pada masing-masing kelas penelitian. Selain itu, peneliti juga melihat kemampuan berpikir kreatif siswa berdasarkan perbedaan gender. Penelitian yang dilakukan berjudul "Perbedaan Peningkatan Kemampuan Berpikir Kreatif Siswa SMP melalui Pembelajaran Matematika Berbantuan Puzzle dan Geogebra".

\section{METODE PENELITIAN}

Metode Penelitian yang digunakan adalah metode penelitian kuantitatif. Pada penelitian ini digunakan desain penelitian dalam bentuk kuasi eksperimen. Pemilihan desain yang digunakan pada penelitian ini adalah nonequivalent control group design. Pada desain nonequivalent control group design terdapat pretest, perlakuan yang berbeda, dan posttest dengan diagram seperti berikut (Ruseffendi, 2010)

\begin{tabular}{lll}
$\mathrm{O}_{1}$ & $\mathrm{X}_{1}$ & $\mathrm{O}_{2}$ \\
\hline $\mathrm{O}_{3}$ & $\mathrm{X}_{2}$ & $\mathrm{O}_{4}$
\end{tabular}

Keterangan:

$\mathrm{O}_{1}$ dan $\mathrm{O}_{3}$ : Pretest

$\mathrm{O}_{2}$ dan $\mathrm{O}_{4}$ : Posttest

$\mathrm{X}_{1} \quad$ : Pembelajaran berbantuan puzzle (Perlakuan 1)

$\mathrm{X}_{2} \quad$ : Pembelajaran berbantuan GeoGebra (Perlakuan 2)

Berikut disajikan desain analisis dan keterkaitan antara variabel yang digunakan pada penelitian. 
Tabel 1. Keterkaitan antara Variabel Penelitian

\begin{tabular}{ccc}
\hline \multirow{2}{*}{ Gender $(\mathrm{A})$} & \multicolumn{2}{c}{ Media Pembelajaran $(\mathrm{B})$} \\
& Berbantuan Puzzle $\left(\mathrm{B}_{1}\right)$ & Berbantuan GeoGebra $\left(\mathrm{B}_{2}\right)$ \\
\hline Laki-laki $\left(\mathrm{A}_{1}\right)$ & $\mathrm{A}_{1} \mathrm{~B}_{1}$ & $\mathrm{~A}_{2} \mathrm{~B}_{1}$ \\
Perempuan $\left(\mathrm{A}_{2}\right)$ & $\mathrm{A}_{1} \mathrm{~B}_{2}$ & $\mathrm{~A}_{2} \mathrm{~B}_{2}$ \\
\hline
\end{tabular}

Keterangan:

$\mathrm{B}_{1} \times \mathrm{B}_{2} \quad$ : Perbedaan peningkatan kemampuan berpikir kreatif siswa antara kelas yang berbantuan puzzle dan kelas yang berbantuan GeoGebra.

$\mathrm{A}_{1} \times \mathrm{A}_{2}$ : Perbedaan peningkatan kemampuan berpikir kreatif siswa antara siswa laki-laki dan siswa perempuan.

$\mathrm{B} \times \mathrm{A} \quad$ : Pengaruh interaksi antara penggunaan media pembelajaran dan gender terhadap peningkatan kemampuan berpikir kreatif siswa.

Populasi pada penelitian ini adalah seluruh siswa kelas VIII di SMP Negeri 1 Kota Tangerang. Sampel yang digunakan sebanyak dua kelas yaitu kelas VIII C dan kelas VIII E sebagai kelas eksperimen yang berasal dari populasi yang sama. Adapun teknik pengambilan sampel yang digunakan pada penelitian ini yaitu convenience sampling. Menurut Creswell (2015) teknik convenience sampling yang dilakukan merupakan teknik pengambilan sampel karena ketersediaan sampel dan sesuai untuk menjawab hipotesis. Pemilihan sampel berdasarkan kenyamaan, ketersediaan kelas yang mendapatkan izin dari pihak sekolah, dan kecocokan materi dilakukan dalam melakukan pemilihan sampel. Selain itu, berdasarkan hasil uji inferensial data nilai ujian tengah semester diperoleh bahwa tidak terdapat perbedaan kemampuan pada awal proses pembelajaran antara kelas VIII C dan kelas VIII E.

Instrumen yang digunakan pada penelitian ini adalah instrumen tes dan non tes. Instrumen tes berupa soal uraian kemampuan berpikir kreatif materi Teorema Pythagoras. Instrumen tes telah diuji validitas kepada 33 siswa kelas IX di SMP Negeri 1 Kota Tangerang. Selanjutnya, instrumen non tes berupa lembar observasi dan dokumentasi.

Teknik pengumpulan data terdiri dari pemberian soal pretest dan posttest. Pretest diberikan di awal proses pembelajaran untuk mengetahui kemampuan siswa pada awal pembelajaran. Kemudian, posttest diberikan untuk mengetahui peningkatan kemampuan berpikir kreatif siswa kelas puzzle dan GeoGebra. Selanjutnya, terdapat dua jenis lembar observasi, yaitu lembar observasi kesesuaian proses pembelajaran dan lembar aktivitas siswa. Adapun dokumentasi yang digunakan berupa lembar tes, lembar LKS, foto-foto kegiatan maupun video proses pembelajaran.

Pengolahan data hasil tes dilakukan dengan menggunakan bantuan software SPSS. Semua data yang telah diperoleh akan dianalisis dengan menggunakan uji parametrik ataupun uji non parametrik. Adapun pengolahan data peningkatan kemampuan berpikir kreatif menggunakan perhitungan gain ternormalisasi dilakukan pada masing-masing nilai 
individu siswa. Menurut Bao (2006) rata-rata perhitungan gain ternormalisasi dari sekelompok siswa dapat dilakukan dengan menghitung rata-rata gain ternormalisasi masing-masing siswa pada kelompok tersebut. Seperti yang diungkapkan oleh Sundayana (2015) bahwa gain ternormalisasi digunakan untuk mengetahui peningkatan siswa sebelum dan sesudah pembelajaran. Penyajian perhitungan gain ternormalisasi adalah sebagai berikut (Bao, 2006)

$$
\text { Gain Ternormalisasi }=\frac{\text { skor } \text { posttest }- \text { skor } \text { pretest }}{\text { skor ideal }- \text { skor } \text { pretest }}
$$

Berikut ini disajikan kategori Gain Ternormalisasi

Tabel 2. Kategori Gain Ternormalisasi

\begin{tabular}{cc}
\hline Nilai Gain Ternormalisasi & Interpretasi \\
\hline $0,70<g \leq 1,00$ & Tinggi \\
$0,30<g \leq 0,70$ & Sedang \\
$g \leq 0,30$ & Rendah \\
\hline
\end{tabular}

Sumber: Hake (1999)

Kemudiaan, dilakukan uji perbedaan dua rerata menggunakan uji analysis of variance (ANOVA) untuk mengolah data. Menurut Ali \& Asrori (2014), uji ANOVA dapat digunakan untuk memverifikasi hubungan sebab akibat antara variabel yang digunakan pada penelitian. Uji ANOVA dilakukan setelah mengetahui normalitas dan homogenitas suatu data. Adapun hipotesis yang diuji adalah:

a) Perbedaan peningkatan kemampuan berpikir kreatif

$$
H_{0}: \mu_{1}=\mu_{2}
$$

Rerata nilai gain ternormalisasi antar kelas tidak terdapat perbedaan.

$H_{1}: \mu_{1} \neq \mu_{2}$

Rerata gain ternormalisasi antar kelas terdapat perbedaan.

b) Perbedaan peningkatan kemampuan berpikir kreatif antara siswa lakilaki dan siswa perempuan

$H_{0}$ : Rerata nilai gain ternormalisasi antara siswa laki-laki dan siswa perempuan tidak terdapat perbedaan.

$H_{1}$ : Rerata gain ternormalisasi antara siswa laki-laki dan siswa perempuan terdapat perbedaan.

c) Interaksi yang terdapat antara media pembelajaran dan gender

$H_{0}$ : Tidak terdapat interaksi antara media pembelajaran dan gender terhadap peningkatan kemampuan berpikir kreatif siswa.

$H_{1}$ : Terdapat interaksi antara media pembelajaran dan gender terhadap peningkatan kemampuan berpikir kreatif siswa.

\section{HASIL DAN PEMBAHASAN}

\section{Hasil}

Perhitungan statistik deskriptif yang diperoleh dari nilai N-Gain disajikan pada Tabel 3. Dapat dilihat bahwa nilai rata-rata pretest kelas 
puzzle lebih tinggi dari pada nilai rata-rata pretest kelas GeoGebra. Hal serupa juga terlihat bahwa nilai N-Gain kelas puzzle lebih tinggi dari kelas GeoGebra. Namun, untuk perhitungan nilai standar deviasi terlihat bahwa standar deviasi kelas GeoGebra lebih tinggi dari kelas puzzle.

Tabel 3. Data N-Gain Kemampuan Berpikir Kreatif

\begin{tabular}{ccccccc}
\hline Kelas & N & Perhitungan & Pretest & Posttest & $\begin{array}{c}\text { N- } \\
\text { Gain }\end{array}$ & Interpretasi \\
\hline Puzzle & \multirow{2}{*}{34} & Rata-Rata & 2,41 & 16,44 & 0,64 & Sedang \\
& & Std. Deviasi & 1,78 & 4,72 & & \\
GeoGebra & \multirow{2}{*}{34} & Rata-Rata & 2,18 & 13,35 & 0,52 & Sedang \\
& & Std. Deviasi & 2,25 & 5,37 & & \\
\hline
\end{tabular}

Keterangan: Skor maksimal ideal adalah 24

Selanjutnya, dilakukan uji statistik inferensial. Adapun hasil pengolahan data yang pertama dilakukan adalah melakukan uji normalitas. Diperoleh nilai signifikansi yang sama antara kelas puzzle dan kelas GeoGebra yaitu 0,20. Oleh karena itu, dapat disimpulkan bahwa kedua kelas memiliki data yang berdistribusi normal. Kemudian, dilakukan uji homogenitas karena kedua kelas memiliki sebaran data yang berdistribusi normal. Berdasarkan hasil uji homogenitas, diperoleh nilai signifikansi lebih dari taraf signifikan yaitu sebesar 0,89. Artinya antara kelas puzzle dan GeoGebra memiliki variansi data yang homogen.

Kemudian, dilakukan pengolahan data menggunakan uji ANOVA untuk menjawab rumusan masalah penelitian. Adapun hasil pengolahan data yang dilakukan dapat dilihat pada Tabel 4 .

Tabel 4. Uji ANOVA Data N-Gain Kemampuan Berpikir Kreatif

\begin{tabular}{cccl}
\hline $\begin{array}{c}\text { Sumber } \\
\text { Varians }\end{array}$ & Signifikansi & Keputusan & \multicolumn{1}{c}{ Kesimpulan } \\
\hline Media & 0,02 & Terima $H_{1}$ & $\begin{array}{l}\text { Terdapat perbedaan rerata N- } \\
\text { Gain antara kelas puzzle dan } \\
\text { kelas GeoGebra. }\end{array}$ \\
Gender & 0,37 & Terima $H_{0}$ & $\begin{array}{l}\text { Tidak ada perbedaan rerata N- } \\
\text { Gain antara siswa laki-laki dan } \\
\text { siswa perempuan. }\end{array}$ \\
Media*Gender & 0,24 & Terima $H_{0}$ & $\begin{array}{l}\text { Tidak terdapat interaksi antara } \\
\text { media pembelajaran dan } \\
\text { gender terhadap peningkatan } \\
\text { kemampuan berpikir kreatif } \\
\text { siswa. }\end{array}$ \\
\hline & & &
\end{tabular}

Pada Tabel 4 apabila dilihat dari penggunaan media yang digunakan maka nilai signifikansi yaitu 0,02 kurang dari taraf signifikan. Hal ini dapat dikatakan bahwa, nilai rerata N-Gain kelas puzzle dan GeoGebra terdapat perbedaan. Artinya, terdapat perbedaan peningkatan kemampuan berpikir kreatif siswa antara kelas puzzle dan GeoGebra. 
Selanjutnya, apabila nilai signifikansi 0,02 dibandingkan dengan setengah dari taraf signifkansi dengan nilai $\frac{0.05}{2}=0,025$ maka diperoleh nilai signifikansi kurang dari taraf signifikansi. Hal ini menunjukkan bahwa rerata N-Gain kelas puzzle lebih dari rerata N-Gain kelas GeoGebra. Artinya, peningkatan kelas puzzle lebih besar dari pada dari pada peningkatan kelas GeoGebra.

Selanjutnya apabila dilihat dari perbedaan gender maka nilai signifikansi yaitu 0,37 lebih dari taraf signifikan. Hal ini berarti bahwa tidak terdapat perbedaan rerata nilai $N$-Gain siswa laki-laki dan rerata nilai $N$-Gain siswa perempuan. Artinya tidak terdapat peningkatan kemampuan berpikir kreatif antara siswa laki-laki dan siswa perempuan.

Selain itu, jika dilihat dari perbedaan penggunaan media puzzle maupun media Geogebra serta faktor gender maka nilai signifikansi yaitu 0,24 lebih dari taraf signifikan. Hal ini menunjukkan bahwa peningkatan rerata nilai $\mathrm{N}$-Gain pada penggunaan media tidak mempengaruhi peningkatan rerata nilai $\mathrm{N}$-Gain pada faktor gender. Artinya, dapat disimpulkan bahwa tidak terdapat interaksi antara media dan gender terhadap kemampuan berpikir kreatif siwa.

\section{Pembahasan}

Pada kelas puzzle siswa diminta untuk memahami Teorema Pythagoras menggunakan 3 macam Pythagorean puzzle. Selanjutnya, siswa menemukan berbagai ukuran segitiga yang memenuhi Teorema Pythagoras menggunakan pythagorean stick Kemudian, dilanjutkan dengan eksplorasi menggunakan magic triangle untuk menemukan bilanganbilangan yang memenuhi Teorema Pythagoras. Hal ini sesuai pendapat Aroya \& Yusuf (2013) bahwa penggunaan media puzzle dapat membantu siswa untuk berpikir kreatif dan bergerak aktif.
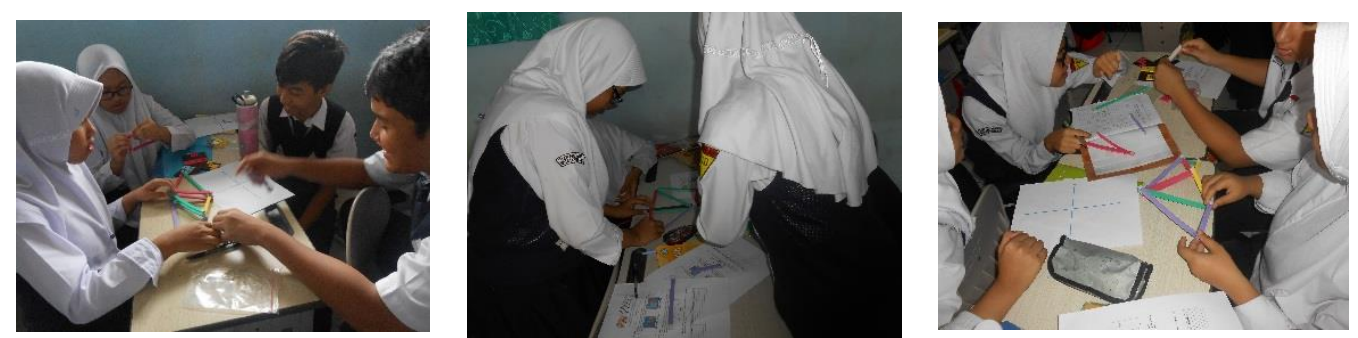

Gambar 1. Siswa Menemukan Berbagai Ukuran Segitiga Siku-Siku

Siswa yang bereksplorasi menggunakan puzzle lebih bisa membuat berbagai ukuran yang membentuk segitiga siku-siku menggunakan pythagorean stick. Selain itu, siswa juga menemukan berbagai ukuran triple menggunakan magic triangle. Hal ini terlihat bahwa siswa lebih banyak menemukan kombinasi bilangan triple Pythagoras menggunakan pythagorean stick dan magic triangle.

Selanjutnya, di kelas GeoGebra setiap kelompok membuat berbagai ukuran segitiga siku-siku untuk dapat menunjukkan kebenaran Teorema 
Pythagoras. Siswa membuat berbagai ukuran segitiga siku-siku dengan ukuran yang bervariatif, misalnya dengan menggunakan satu ukuran sisi segitiga yang merupakan bilangan bulat, dua ukuran sisi segitiga bilangan bulat, atau semua sisi segitiga dengan ukuran bilangan bulat. Siswa kelas GeoGebra lebih aktif pada aktivitas menunjukkan kebenaran Teorema Pythagoras dari pada siswa kelas puzzle. Berdasarkan hasil observasi, siwa kelas GeoGebra siswa di kelas GeoGebra lebih aktif saat melakukan eksplorasi. Sesuai dengan pendapat Mahmudi (2010), eksplorasi menggunakan GeoGebra dapat memunculkan ide-ide baru. Siswa lebih bisa bereksplorasi menggunakan GeoGebra tanpa adanya batas ukuran yang digunakan untuk membuat segitiga siku-siku yang diinginkan. Keaktifan siswa dalam mengikuti proses pembelajaran dapat dilihat dengan adanya antusiasme seperti yang terlihat pada gambar berikut.
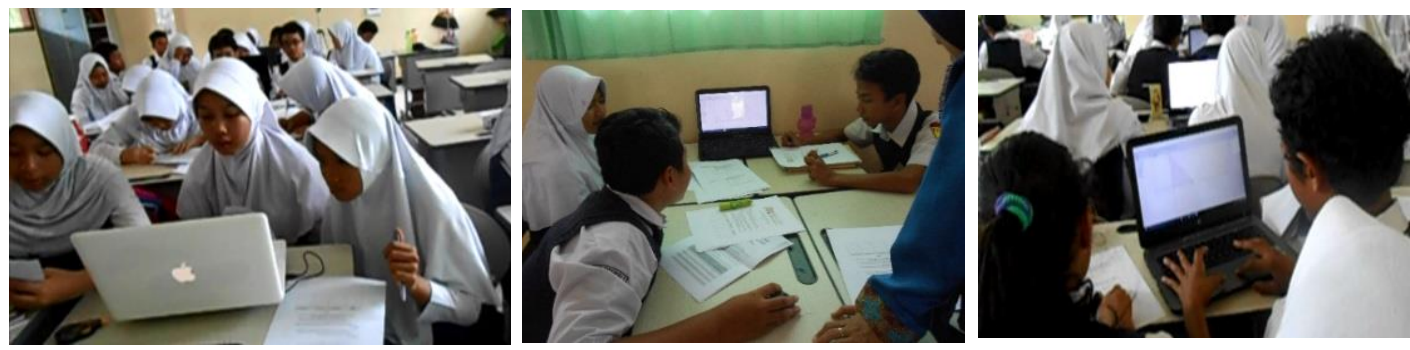

Gambar 2. Siswa Melakukan Eksplorasi Menggunakan GeoGebra

Dilakukan pemberian posttest setelah selesai dilakukan proses pembelajaran. Berdasarkan hasil perhitungan statistik inferensial diperoleh bahwa terdapat perbedaan kemampuan berpikir kreatif siswa kelas puzzle dan kelas GeoGebra. Hasil penelitian sesuai dengan penelitain relevan yang dilakukan Nurafni (2014), yaitu terdapat perbedaan hasil belajar penggunaan media dan alat peraga. Selanjutnya, berdasarkan hasil perhitungan statistik inferensil diperoleh bahwa kemampuan berpikir kreatif siswa pada kelas puzzle lebih besar daripada kelas GeoGebra. Hal ini dikarenakan nilai rerata $N$-Gain kelas puzzle lebih dari nilai rerata $N$-Gain kelas GeoGebra. Keadaan ini sejalan dengan pendapat Aroya \& Yusuf (2013) bahwa media pembelajaran puzzle dapat meningkatkan kemampuan berpikir kreatif siswa dalam proses pembelajaran.

Berdasarkan faktor gender tidak mempengaruhi perbedaan kemampuan berpikir kreatif siswa. Siswa laki-laki dan siswa perempuan terlihat memiliki kemampuan berpikir kreatif yang sama. Hasil ini diperoleh berdasarkan hasil perhitungan dan juga observasi yang dilakukan selama proses pembelajaran berlangsung. Tidak terdapat perbedaan kemampuan siswa dalam menyelesaikan permasalahan kemampuan berpikir kreatif antara siswa laki-laki dan siswa perempuan. Selain itu, partisipasi siswa terlihat sama selama proses pembelajaran antara siswa laki-laki dan siswa perempuan. Siswa laki-laki memiliki kemampuan sama dengan siswa perempuan pada saat melakukan eksplorasi menggunakan puzzle atau GeoGebra. 
Pada hasil uji ANOVA menunjukkan bahwa tidak terdapat interaksi antara penggunaan media dan faktor gender terhadap peningkatan kemampuan berpikir kreatif siswa. Artinya, penggunaan media puzzle maupun GeoGebra terdapat perbedaan dalam meningkatkan kemampuan berpikir kreatif siswa tanpa memperlihatkan faktor gender. Hal ini dapat dikatakan bahwa, apabila ingin meningkatkan kemampuan berpikir kreatif siswa maka dapat dilakukan menggunakan media dengan mengabikan faktor gender yang ada.

\section{KESIMPULAN DAN SARAN}

Berdasarkan hasil penelitian yang dilakukan di SMP Negeri 1 Kota Tangerang pada materi Teorema Pythagoras maka kesimpulan yang diperoleh dari penelitian ini adalah terdapat perbedaan peningkatan kemampuan berpikir kreatif antara siswa yang mendapat pembelajaran berbantuan puzzle dan siswa yang mendapat pembelajaran GeoGebra. Kemudian tidak terdapat perbedaan peningkatan kemampuan berpikir kreatif antara siswa laki-laki dan siswa perempuan. Selain itu, tidak terdapat interaksi antara media pembelajaran dan gender terhadap peningkatan kemampuan berpikir kreatif siswa.

Adapun saran yang dapat direkomendasikan untuk penelitian selanjutnya adalah pertimbangkan waktu pelaksanaan penelitian, jangan sampai proses pelaksanaan terjadi pada waktu yang tidak kondusif untuk siswa mengikuti proses pembelajaran. Selanjutnya dapat dilakukan penelitian dengan materi lain selain materi Teorema Pythagoras dengan menggunakan media puzzle atau GeoGebra. Selain itu, dapat juga dilakukan untuk mengukur kemampuan lainnya selain kemampuan berpikir kreatif.

\section{DAFTAR RUJUKAN}

Ali, M., \& Asrori, M. (2014). Metodologi dan Aplikasi Riset Pendidikan. Bandung: Bumi Aksara.

Amri, S. (2015). Implementasi Pembelajaran Aktif dalam Kurikulum 2013. Jakarta: Prestasi Pustakarya.

Anthaqo, I. N., \& Muhsetyo, G. (2013). Penggunaan Media Puzzle Magnet untuk Meningkatkan Hasil Belajar Siswa SMPN 1 Trawas tentang Kubus \& Balok melalui Model Problem Based Instruction (PBI).

Aroya, R., \& Yusuf, A. (2013). Pengaruh Media Pembelajaran Puzzle Terhadap Peningkatan Kemampuan Calistung Peserta Didik Pendidikan Keaksaraan Fungsional Tingkat Dasar di UPTD. Journal Plus UNESA.

Arsyad, A. (2015). Media Pembelajaran. Jakarta: Rajawali Pers.

Atikasari, G., \& Kurniasih, A. W. (2015). Keefektifan Model Pembelajaran Kooperatif dengan Strategi TTW Berbantuan GeoGebra terhadap Kemampuan Berpikir Kreatif Matematis Siswa Kelas VII Materi Segitiga. Unnes Journal of Mathematics Education.

Bao, L. (2006). Theorical Comparison of Average Normalized Gain Calculation. American Journal of Physics.

Creswell, J. (2015). Riset Pendidikan: Perencanaan, Pelaksanaan, dan Evaluasi 
Riset Kualitatif \& Kuantitaif (5 ed.). (H. P. Soetjipto, \& S. Mulyantini, Trans.) Pustaka Pelajar.

Dewi, A., Kusuma, \& Kurniasih, N. (2016). Peningkatan Penalaran dan Komunikasi Matematis Siswa dengan CMP Kelas VII G SMP Negeri 3 Gombong. Ekuivalen 20.

Ervynck, G. (1991). Mathematical Creativity. Journal Advanced Mathematical Thinking.

Hake, R. R. (1999). Analyzing Change/Gain Scores. Retrieved from http://www.physics.indiana.edu/ sdi/AnalyzingChange-Gain.pdf

Hartadiyati, E., Utami, R. E., \& Rubowo, M. R. (2015). Pengembangan Media Pembelajaran Puzzle Card untuk Meningkatkan Kemampuan Berpikir Kreatif Siswa. Seminar Nasional Pendidikan Sains. Surakarta: Magister Pendidikan Saind dan Doktor Pendidikan IPA FKIP UNS.

Haylock, D. W. (1987). A Framework for assessing mathematical creativity in school children. Journal of Education Studies in Mathematics.

Hendriana, H., \& Sumarmo, U. (2014). Penilaian Pembelajaran Matematika. Bandung: Refika Aditama.

Herman, T. (2007). Pembelajaran Berbasis Masalah Untuk Meningkatkan Kemampuan Berpikir Matematis Tingkat Tinggi Siswa Sekolah Menengah Pertama. Educationist.

Hohenwarter, M., \& Fuchs, K. (2004). Combination of Dynamic Geometry and Algebra in The Software System GeoGebra. Journal ZDM.

Katminingsih, Y., \& Widodo, S. (2015). Pengaruh Model Pembelajaran Berdasarkan Masalah Terhadap Kemampuan Berpikir Kreatif Matematis Siswa Ditinjau Menurut Gender Siswa SD Negeri Tarokan Kediri. Jurnal Math Educator Nusantara.

Mahmudi, A. (2010). Membelajarkan Geometri dengan Program GeoGebra. Seminar Nasional Matematika dan Pendidikan Matematika. Yogyakarta: Pendidikan Matematika FMIPA Universitas Negeri Yogyakarta.

Noer, S. H. (2014). Kemampuan Berpikir Kreatif Matematis dan Pembelajaran Matemtika Berbasis Masalah Open-Ended. Jurnal Pendidikan Matematika.

Nurafni. (2014). Perbedaan Hasil Belajar Matematika Siswa dengan Menggunakan Media Alat Peraga Sederhana dan Powerpoint. Seminar Nasional Pendidikan Matematika. Jakarta Selatan: Prodi Matematika UHAMKA.

Nurmasari, N., Kusmayadi, T. A., \& Riyadi. (2014). Analisis Berpikir Kreatif Siswa dalam Menyelesaikan Masalah Matematika pada Materi Peluang Ditinjau dari Gender. Jurnal Elektronik Pembelajaran Matematika.

Primasari, R., Zulfiati, \& Herlanti, Y. (2014). Penggunaan Media Pembelajaran di Madrasah Aliah Negeri se-Jakarta Selatan. Jurnal EDUSAINS.

Rahman, R. (2012). Hubungan antara Self-Concept terhadap Matematika dengan Kemampuan Berpikir Kreatif Matematik Siswa. Jurnal Ilmiah Program Studi Matematika STKIP Siliwangi Bandung.

Ruseffendi, E. T. (2010). Dasar-Dasar Penelitian Pendidikan dan Bidang NonEksakta Lainnya. Bandung: Tarsito.

Santrock, J. W. (2014). Psikologi Pendidikan: Educational Psychology (5 ed.). (H. Bhimasena, Trans.) Jakarta: Salemba Humanika.

Sari, I. P., \& Yuniarti, T. (2015). Open-ended Problems untuk Mengembangkan 
Kemampuan Berpikir Kreatif Siswa. Seminar Nasional Matematika dan Pendidikan Matematika. Yogyakarta: Universitas Negeri Yogyakarta.

Sundayana, R. (2015). Statistika Penelitian Pendidikan. Bandung: Alfabeta.

Torrance, E. P. (1972). Predictive Validity of the Torrance Tests of Creative Thinking. The Journal of Creative Behaviour.

Wardaya, P., Kurniasih, N., \& Maryam, I. (2014). Peningkatan Kreativitas dan Pemaham Konsep Siswa Melalui Model Pembelajaran Berbasis ICT Berbantuan Software GeoGebra Pada Materi Segiempat. E-Journal EKUIVALEN-Pendidikan Matematika.

Wardhani, S., \& Rumiati. (2011). Instrumen Penilaian Hasil Belajar Matematika SMP: Belajar dari PISA dan TIMSS. Kemendiknas. 